\title{
Correction to: Adaptive market-oriented combinatorial double auction resource allocation model in cloud computing
}

\section{Asif Umer ${ }^{1} \cdot$ Babar Nazir $^{2} \cdot$ Zulfqar Ahmad $^{1}$}

Published online: 21 July 2021

(c) Springer Science+Business Media, LLC, part of Springer Nature 2021

\section{Correction to: The Journal of Supercomputing https://doi.org/10.1007/s11227-021-03918-x}

During proof correction, it was missed to assign the correct corresponding author.

The correct version is given below:

Babar Nazir

babarnazir@gmail.com

The original article has been corrected.

Publisher's Note Springer Nature remains neutral with regard to jurisdictional claims in published maps and institutional affiliations.

The original article can be found online at https://doi.org/10.1007/s11227-021-03918-x.

Babar Nazir

babarnazir@gmail.com

1 Department of Computer Science and Information Technology, Hazara University, Mansehra 21300, Pakistan

2 Department of IT and Computer Science, Pak-Austria Fachhochschule: Institute of Applied Sciences and Technology, Haripur, Khyber Pukhtunkhwa, Pakistan 